Research Article

\title{
Biodegradation of low-density polyethylene plastics by fungi isolated from waste disposal site at district Peshawar, Pakistan
}

\author{
Ali Hyder ${ }^{1}$, Muddasir Khan ${ }^{1 *}$, Saifullah Khan ${ }^{2}$, Madiha Iqbal $^{3}$, Sohail Ahmad Jan ${ }^{4}$, Syed Hussain Shah ${ }^{1}$, Abdullah$^{1}$, \\ Ziaur Rahman ${ }^{5}$ and Umer Iqbal ${ }^{1}$
}

Citation: Hyder, A.; Khan, M.; Khan, S.; Iqbal, M.;Jan, SA.; Shah, SH.; Abdullah; Rahman, Z.; Iqbal, U. Biodegradation of low-density polyethylene plastics by fungi isolated from waste disposal site at district Peshawar, Pakistan. Pakistan Journal of Biochemistry and Biotechnology, 2021, 2 (2), 127-133. https://doi.org/10.52700/pjbb.v2i2.59

Received: 16-09-2021

Accepted: 17-12-2021

Published: 31-12-2021
1 Department of Health and Biological Sciences, Abasyn University Peshawar, Pakistan 2 Institute of Biotechnology and Microbiology, Bacha Khan University Charsadda, Pakistan 3 Department of Botany, Shaheed Benazir Bhutto Women University Peshawar, Pakistan 4 Department of Bioinformatics and Biosciences, Capital University of Science and Technology, Pakistan 5 Food Technology Centre, PCSIR Laboratories Complex, Peshawar, Pakistan

* Correspondence: muddasir.khan0302@gmail.com, mk03025678947@gmail.com

\begin{abstract}
Plastics are resistant to microbial attacks, which has become a major cause of environmental pollution. The current study aimed to identify fungi, capable to degrade the low-density polyethylene plastics from different waste disposal sites at Peshawar, Pakistan. A total of 15 soil samples were collected from Peshawar's several garbage disposal locations, including Gunj Gate, Gulbahar, Jamil Chowk, Nishtarabad, Ring Road, and Agha Mir Jani Road. From these samples, four fungal isolates Aspergillus Niger, Aspergillus flavus, White rot, and Brown rot fungi were identified based on their colony morphology and microscopic examination. The biodegradation ability of these isolates against low-density polyethylene plastics was studied through the weight loss percentage method at 30 days of incubation. The weight loss percentage showed that Aspegillus Niger, Aspergillus flavus, Brown rot, and white rot fungi showed $22.9 \%, 16.1 \%, 18.4 \%$, and $22.7 \%$ biodegradation, respectively. This study concluded that Aspergillus Niger, Aspergillus flavus, White rot, and Brown rot fungi are capable to degrade polyethylene plastics. The current study recommended that large scale studies should be performed for better degradation of large concentration of polyethylene and more research work is needed to explore more biodegradable fungi.
\end{abstract}

Keywords: Low density polyethylene; Plastics; Fungi; Biodegradation

\section{Introduction}

The word plastic is derive from a Greek word "plastikos", meaning "able to be molded into various shapes". Plastics are resistant to microbial attack because evolution has been unable to generate novel enzyme structures capable of dissolving synthetic polymers during their brief existence in nature and the environment [1]. Today, more than 140 million tons of petroleum-based synthetic polymers are produced worldwide each year, with large amounts of these polymers entering the ecosystem as industrial waste products [2]. This usage is still increasing at a rapid rate of $12 \%$ each year. They have substituted paper and other cellulose-based products for packaging due to their better physical and chemical properties, such as strength, lightness, toughness, flexibility, and resistance to water and most water-borne microorganisms. Polyethylene, polypropylene, polystyrene, polyvinyl chloride, polyurethane, polyethylene terephthalate, polybutylene terephthalate, and nylons are most often used in packaging. Plastics are widely used not just because of their advantageous mechanical and thermal qualities, but also because of their stability and durability $[3,4]$. 
Although certain synthetic plastics are biodegradable, such as polyester polyurethane and polyethylene with starch blend, the bulk of commodity plastics on the market today are either non-biodegradable or take decades to degrade. This has inspired a surge in research around the world to either change existing products to improve degradability or develop new alternatives that degrade via any or all of the specific mechanisms indicated below: biodegradation, photodegradation, environmental erosion, and thermal degradation. Microorganisms such as bacteria and fungi aid in the degradation of natural and artificial polymers [5].

Various bacteria and fungus are involved in the biodegradation process, and these fungi are also involved in the utilization of polyethylene, such as; Brevibacillus borstelensis [6, 7], Rhodococcus rubber [8], Penicillium simplicissimum [9], Comamonas Acidovorans TB-35 [10], Curvularias enegalensis [11], Fusarium solani, Brown Rot Fungi, Streptomyces species, Aureobasidium pullulans, Cladosporium spp., Pseudomonas chlororaphis [12, 13], Pseudomonas putida, Rhodococcus [14], Ochrobactrum TD, Pseuadomonas fluorescens B-22, Aspergillus niger [13], Van Tieghem F-1119, Aureobasidium pullulans [15], Thermomonsporafusca Kleeberg, Fusariumm oniliforme, Penicillium Roqueforti, and Aspergillus flavus [16].

Therefore, the goal of this study was to identify the fungi from waste disposal sites at Peshawar, Pakistan. Furthermore, the isolated fungi were screened for the biodegradation potential against low-density polyethylene plastics.

\section{Materials and Methods}

\subsection{Sample collection and Study area}

Soil samples were taken from Peshawar's several garbage disposal locations, including Gunj Gate, Gulbahar, Jamil Chowk, Nishtarabad, Ring Road, and Agha Mir Jani Road. A total of 15 soil samples were taken from a depth of 3-5 cm and promptly sealed in sterilized bags before being transported to the Abasyn University Peshawar microbiology lab for fungal isolation.

\subsection{Isolation of Low-Density Polyethylene degrading fungi}

In a shaker incubator, one gram of soil and one gram of plastic trash were suspended in $50 \mathrm{ml}$ of sterile distilled water and incubated for 30 minutes at $150 \mathrm{rpm}$ at $28^{\circ} \mathrm{C}$, then $0.1 \mathrm{ml}$ of each suspension was placed directly on the surface of the Potato Dextrose and Sabouraud dextrose medium plates. The plates were incubated at the temperature of $28^{\circ} \mathrm{C}$ for 24 hours [17].

\subsection{Identification of fungal isolates}

The morphological (colony colour and margins colour) and microscopic properties of fungal isolates were used to identify them. For microscopy, one drop of lactophenol blue was added to the slide. Fungal culture was emulsified on it. Then, the slide was fixed by a coverslip. The slide was observed under a microscope and fungal isolates were identified based on their hyphae, spores, and sporangium [18].

\subsection{Biodegradation of isolated fungi}

Minimal salt media with composition; $\mathrm{NaNO}_{3}(6.0 \mathrm{gm} / \mathrm{l}), \mathrm{KCl}(0.52 \mathrm{gm} / \mathrm{l})$, $\mathrm{MgSO}_{4} .7 \mathrm{H}_{2} \mathrm{O}(0.52 \mathrm{gm} / \mathrm{l}), \mathrm{KH}_{2} \mathrm{PO}_{4}(1.52 \mathrm{gm} / \mathrm{l})$, Glucose (dextrose) $(10.0 \mathrm{gm} / \mathrm{l})$, and Difco Agar $(15.0 \mathrm{gm} / \mathrm{l})$, was prepared for in-situ degradation of plastics under laboratory conditions. Pre-weighed discs of $2 \times 2 \mathrm{~cm}$ diameter prepared from low-density polyethylene and 
weighed initially. The plastic disc was transferred to a conical flask containing $50 \mathrm{~mL}$ of distilled water in an aseptic manner. Potato Dextrose Broth was prepared; inoculum was added to it and incubated for 24 hours. After this, minimal salt media (MSM) was prepared for five flasks ( 4 for test purposes and 1 for control). The fungal isolates in potato dextrose broth were added to each of the flasks as a consortium. Plastic discs in the microbe-free media were used to maintain control. Each variety of plastic was maintained in its own flask, and labeled. The flasks were shaken for 30 days at $28^{\circ} \mathrm{C}$ and $150 \mathrm{rpm}$ in a shaking incubator. The plastic discs were collected after one month of incubation, rinsed thoroughly with distilled water, and then centrifuged with distilled water to eliminate any contaminants and germs from the plastic strips. The plastic samples were then shade dried and weighed to determine their final weight, and the weight loss \% was calculated. Plastic weight loss percentage was calculated using the below formula [19].

$$
\begin{gathered}
\% \text { Decrease of plastic weight }=\frac{\mathrm{RI}-\mathrm{R} 2}{\mathrm{RI}} \times 100 \\
(\mathbf{R} 1)=\text { Initial Weight of plastic film } \\
(\mathbf{R} 2)=\text { Final weight of plastic film }
\end{gathered}
$$

\section{Result and Discussion}

Total 05 fungal isolates were identified based on their morphology, color, and microscopic results, shown in Table 1, Figures 1 \& 2. Using a consortium of fungal species, Aspergillus Niger showed 22.90\%, Aspergillus Flavus showed 16.10\%, White Rot Fungi showed $18.4 \%$, and Brown Rot Fungi showed $22.7 \%$ of low-density polyethylene plastics weight loss (Table 2).

\begin{tabular}{|c|c|c|c|c|c|c|}
\hline $\begin{array}{l}\text { Code } \\
\text { No. }\end{array}$ & $\begin{array}{l}\text { Plate Morphol- } \\
\text { ogy }\end{array}$ & Hyphae & Spores & Sporangium & Fungal isolates & Source \\
\hline BS001 & $\begin{array}{c}\text { Dark Greenish } \\
\text { color with } \\
\text { white edge }\end{array}$ & Septate & $\begin{array}{l}\text { Round } \\
\text { spores }\end{array}$ & $\begin{array}{l}\text { Clear Sporan- } \\
\text { gium }\end{array}$ & Aspergillus Niger & Jamil Chowk Peshawar \\
\hline BS002 & $\begin{array}{l}\text { Light greenish } \\
\text { yellow color } \\
\text { with white } \\
\text { edge }\end{array}$ & Septate & $\begin{array}{l}\text { Clear } \\
\text { round } \\
\text { spores }\end{array}$ & $\begin{array}{l}\text { Clear Sporan- } \\
\text { gium }\end{array}$ & $\begin{array}{c}\text { Aspergillus Fla- } \\
\text { vus }\end{array}$ & Gunj Gate \\
\hline BS003 & $\begin{array}{c}\text { Full white color } \\
\text { with full white } \\
\text { edge }\end{array}$ & $\begin{array}{l}\text { Septate } \\
\text { having } \\
\text { holes in } \\
\text { hyphae }\end{array}$ & No spores & No sporangium & $\begin{array}{c}\text { White Rot } \\
\text { Fungi }\end{array}$ & Gulbahar \\
\hline BS004 & $\begin{array}{l}\text { Light brown } \\
\text { color with } \\
\text { white edge. }\end{array}$ & $\begin{array}{l}\text { Septate } \\
\text { having } \\
\text { holes in } \\
\text { hyphae }\end{array}$ & No spores & No sporangium & Brown Rot Fungi & Nishterabad \\
\hline
\end{tabular}

Table 1. Colony Morphology and microscopic examination of different fungal isolates from waste Disposal Sites at Peshawar, Khyber Pakhtunkhwa, Pakistan 

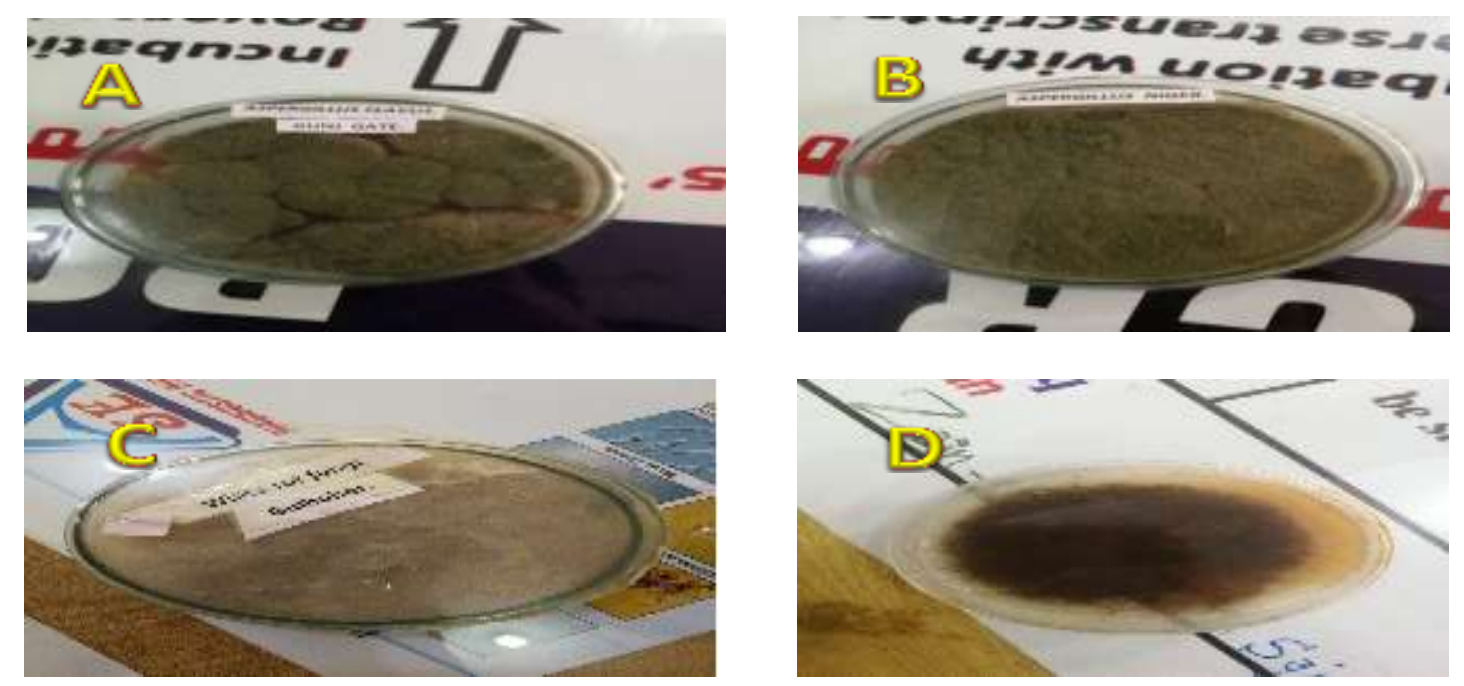

Figure 1. Different isolated fungi colony Morphology, (A) Aspergillus Flavus, (B) Aspergillus Niger, (C) White Rot Fungi, and (D) Brown Rot Fungi
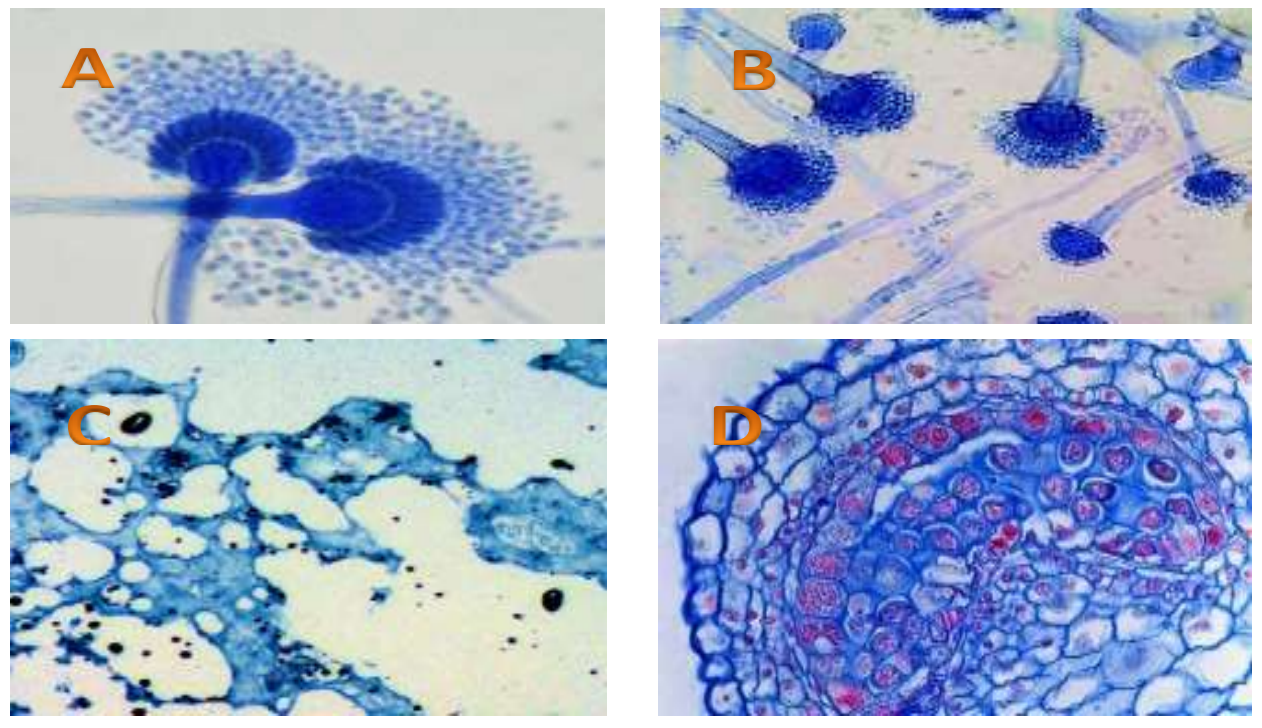

Figure 2. Different isolated fungi Microscopic examination, (A) Aspergillus Flavus, (B) Aspergillus Niger, (C) White Rot Fungi, and (D) Brown Rot Fungi 
Table 2. Biodegradation ability of fungal isolates against low density polyethylene plastics

\begin{tabular}{ccccc}
\hline Fungal isolates & $\begin{array}{c}\text { Initial } \\
\text { weight } \mathbf{( m g})\end{array}$ & $\begin{array}{c}\text { Final weight } \\
(\mathbf{m g})\end{array}$ & $\begin{array}{c}\text { Weight Loss } \\
(\mathbf{m g})\end{array}$ & $\begin{array}{c}\text { Biodegradation } \\
\mathbf{( \% )}\end{array}$ \\
\hline Aspergillus Niger & 17.4 & 13.4 & 4 & $22.90 \%$ \\
Aspergillus Flavus & 18.6 & 15.6 & 3 & $16.10 \%$ \\
White Rot Fungi & 9.2 & 7.5 & 7.2 & $18.40 \%$ \\
Brown Rot Fungi & 4.4 & 3.4 & 1 & $22.70 \%$ \\
\hline
\end{tabular}

Microorganisms play a vital role in the biological breakdown of materials, including artificial polymers, in the natural world. Extracellular and intracellular depolymerizes are two types of enzymes involved in the biological destruction of polymers during the depolymerization process [5]. Microorganisms' exo-enzymes break down complex polymers into simpler molecules with short chains, such as oligomers, dimmers, and monomers, which can pass through germs' semi-permeable outer membranes and be used as carbon and energy sources [16].

Muhonja et al. [20] studied the biodegradation process of polythene and plastic by bacteria including; Pseudomonas species, Bacillus subtilis, Streptococcus lactis, Micrococcus species, Streptococcus mutans, Proteus vulgaris, and Staphylococcus aureus, fungi including; Aspergillus glaucus, Aspergillus nidulance, and Penicillium species. They originate that these types of microorganisms degraded the plastic efficiently. While in the current study Aspergillus Niger, Aspergillus flavus, White rot, and Brown rot fungi showed plastic degradation efficiently. Several research has been carried out to look into the ability of different species of fungi to biodegrade plastics. Aureobasidium pullulans isolated from waste soil in India, including Rhodotorula aurantiaca and Kluyveromyces species, were also found to be capable of biodegrading polyethylene plastic bags [19]. In the delta mangrove of niger, Immanuel et al. [21] discovered strains of Aspergillus japonicus and Aspergillus terreus that could breakdown plastics including; high-density polyethylene and low-density polyethylene sheets. Raaman et al. [22] found that Aspergillus flavus and Mucor species degrade polyethylene in India.

Sharma et al. [23] studied that A. flavus (ITCC No. 6051), A. fumigatus (ITCC No. 6050), A. niger (ITCC No. 6052) showed 4.41, 3.45, $1.16 \%$ reduction in weight, 61.33, 60, and $58.77 \%$ reduction in tensile strength of the polyethylene film after incubation with the respective isolate for 30 days. While in the current study Aspegillus Niger, Aspergillus flavus, Brown rot, and white rot fungi showed $22.9 \%, 16.1 \%, 18.4 \%$, and $22.7 \%$, respectively, reduction in tensile strength of the polyethylene film after incubation with the respective isolate for 30 days. According to Deepika et al. [24], plastics have been widely employed as packaging material in the form of low-density polyethylene (LDPE). After microbial attachment to the granules, biodegradation of polymer granules by isolated organisms occurs, resulting in physical and structural changes over time. The weight method was used in the laboratory for 2, 4, and 6 months to check the efficacy of the biodegradation process. Streptomyces species had the highest plastic degradation capacity, degrading up to $46.7 \%$ over a 6 months period, followed by Pseudomonas species $24.22 \%$, Aspergillus niger $26.17 \%$, and Aspergillus flavus $16.45 \%$. According to this study, Streptomyces plays a major role in the breakdown of polythene powder and polymer granules. While in the current study, the weight loss was calculated after one month of incubation. The weight loss percentage showed that Aspegillus niger, Aspergillus flavus, Brown rot, and white rot fungi showed biodegradation potential $22.9 \%, 16.1 \%, 18.4 \%$, and $22.7 \%$, respectively. 


\section{Conclusions}

This study concluded that Aspergillus Niger, Aspergillus flavus, White rot, and Brown rot fungi isolated from several garbage disposal locations, including Gunj Gate, Gulbahar, Jamil Chowk, Nishtarabad, Ring Road, and Agha Mir Jani Road in Peshawar, Pakistan, are capable to degrade polyethylene plastics. Based on these findings, it is recommended that; experiments should be performed on large scale for the better degradation of the large concentration of polyethylene. More research is needed to uncover more isolates of fungal species capable of degrading various forms of plastics, particularly those that are important contributors of pollution in the environment.

Author Contributions: All included authors contributed equally. All authors have read and agreed to the published version of the manuscript.

\section{Funding: Nil}

Acknowledgments: Authors are thankful to the Department of Health and Biological Sciences, Abasyn University Peshawar, Pakistan for providing platform.

Conflicts of Interest: The authors declare no conflict of interest.

\section{References}

1. El-Sayed, M.T.; Rabie, G.H.; Hamed, E.A. Biodegradation of low-density polyethylene (LDPE) using the mixed culture of Aspergillus carbonarius and A. fumigates. Environment, Development and Sustainability. 2021, 1-29.

2. Shimao, M. Biodegradation of plastics. Current Opinion in Biotechnology. 2001, 12(3); 242-7.

3. Din, M.; Nelofer, R.; Salman, M.; Khan, F.H.; Khan, A.; Ahmad, M.; Khan, M. Production of nitrogen fixing Azotobacter (SR-4) and phosphorus solubilizing Aspergillus niger and their evaluation on Lagenaria siceraria and Abelmoschus esculentus. Biotechnology Reports. 2019, 22; e00323.

4. Álvarez-Barragán, J.; Domínguez-Malfavón, L.; Vargas-Suárez, M.; González-Hernández, R.; Aguilar-Osorio, G.; Loza-Tavera, $\mathrm{H}$. Biodegradative activities of selected environmental fungi on a polyester polyurethane varnish and polyether polyurethane foams. Applied and environmental microbiology. 2016, 82(17); 5225-5235.

5. Ojha, N.; Pradhan, N.; Singh, S.; Barla, A.; Shrivastava, A.; Khatua, P.; et al. Evaluation of HDPE and LDPE degradation by fungus, implemented by statistical optimization. Scientific Reports. 2017, 7(1); 1-13.

6. Hadad, D.; Geresh, S.; Sivan, A. Biodegradation of polyethylene by the thermophilic bacterium Brevibacillus borstelensis. Journal of Applied Microbiology. 2005, 98; 1093-100.

7. Khan, M.; Salman, M.; Abdullah. High performance liquid chromatography based characterization of Fengycin produced by Bacillus amyloliquefaciens against Fusarium graminearum and Rhizoctonia solani. Kuwait Journal of Science. 2021.

8. Sivan, A.; Szanto, M.; Pavlov, V. Biofilm development of the polyethylenedegrading bacterium Rhodococcus ruber. Applied Microbiology and Biotechnology. 2006, 72(2); 346-52.

9. Ghosh, S.K.; Pal, S. De-polymerization of LDPE plastic by Penicillium simplicissimum isolated from municipality garbage plastic and identified by ITSs locus of rDNA. Vegetos. 2021, 34(1); 57-67.

10. Muthukumar, A.; Veerappapillai, S. Biodegradation of plastics: a brief review. International Journal of Pharmaceutical Sciences Review and Research. 2015, 31(2); 204-209.

11. Howard, G. T. Biodegradation of polyurethane: a review. International Biodeterioration E Biodegradation. 2002,$40 ; 245-52$.

12. Khan, M.; Salman, M.; Jan, S.A. Biological control of fungal phytopathogens: A comprehensive review based on Bacillus species. MOJ Biology and Medicine. 2021, 6(2); 90-92.

13. Zheng, Y.; Yanful, E.K.; Bassi, A.S. A review of plastic waste biodegradation. Critical Reviews on Biotechnology. 2005, 25; 243-50.

14. Anthony, S.D.; Meizhong, L.; Christopher, E.B.; Robin, L.B.; David, L.F. Involvement of linear plasmids in aerobic biodegradation of vinyl chloride. Applied Environmental Microbiology. 2004, 70; 6092-7.

15. Webb, J.S.; Nixon, M.; Eastwood, I.M.; Greenhalgh, M.; Robson, G.D.; Handley, P.S. Fungal colonization and biodeterioration of plasticized polyvinyl chloride. Applied and Environmental Microbiology. 2000, 66(8); 3194-200.

16. Tokiwa, Y.; Calabia, B.P.; Ugwu, C.U.; Aiba, S. Biodegradability of plastics. International journal of molecular sciences. 2009, 10(9); 3722-3742.

17. Esmaeili, A.; Pourbabaee, A.A.; Alikhani, H.A.; Shabani, F.; Esmaeili, E. Biodegradation of Low-Density Polyethylene (LDPE) by Mixed Culture of Lysinibacillus xylanilyticus and Aspergillus niger in Soil. PLoS ONE. 2013, 8(9); e71720.

18. Uddin, M.N.; Khan, M.; Nasrullah. Isolation and identification of fungal pathogens associated with diseases of onion crop in District Swat, Pakistan. Abasyn Journal of Life Sciences. 2019, 2(2); 91-9.

19. Usha, R.; Sangeetha, T.; Palaniswamy, M. Screening of polyethylene degrading microorganisms from garbage soil. Libyan agriculture research center journal international. 2011, 2(4); 200-204.

20. Muhonja, C.N.; Makonde, H.; Magoma, G.; Imbuga, M. Biodegradability of polyethylene by bacteria and fungi from Dandora dumpsite Nairobi-Kenya. PLOS ONE. 2018, 13(7); e0198446.

21. Immanuel, O.M.; Ibiene, A.A.; Stanley, H.O. Enhanced biodegradation of polyethylene by fungus isolated from the koluama mangrove swamp in the Niger Delta. Journal of Microbiology and Biotechnology Research. 2017, 4(2); 1-9. 
22. Raaman, N.; Rajitha, N.; Jayshree, A.; Jegadeesh, R. Biodegradation of plastic by Aspergillus sp. isolated from polythene polluted sites around Chennai. Journal of Academia and Industrial Research. 2012, 1(6); 313-316.

23. Sharma, S.; Rafailovich, M.H.; Sokolov, J.; Liu, Y.; Schwarz, S.A.; Eisenberg, A. Dewetting properties of polystyrene homopolymer thin films on grafted polystyrene brush surfaces. High Performance Polymer. 2000, 12; 581-586.

24. Deepika, S.; Jaya, M.R. Biodegradation of low density polyethylene by microorganisms from garbage soil. Journal of Experimental Biology and Agriculture Sciences. 2015, 3; 15-21. 